getting and utilisation, such as the ventilating and lighting of mines. Of more general interest, a study of the fireproofing of timber showed that ammonium phosphate gave the best results. In fuel technology, the chemistry of coal and coke takes prominence, while combustion in internal combustion engines is under investigation. The prosecution of applied sciences in a university curriculum has received criticism in recent years, but there can be little doubt that the association of teaching with investigation of such technical problems will be of mutual benefit.

\section{Bibliography of Seismology}

WE have received the last quarterly part for the year 1933 of the valuable "Bibliography of Seismology" edited by Mr. E. A. Hodgson and issued by the Dominion Observatory, Ottawa. This part completes the tenth volume and contains the titles, and in some cases brief abstracts, of one hundred memoirs on seismology, published with fow exceptions during the year 1933. The value of the work is much increased by the addition of two indexes, one of the subjects treated during the past year, the other of the authors, more than one thousand in number, whose works are catalogued in the tenth volume (1929-33).

\section{First Tree Ring Conference}

A CONFERENCE on tree ring studies was held on June 11-12, at the Museum of Northern Arizona at Flagstaff, under the chairmanship of Dr. A. E. Douglass of the University of Arizona. Among the problems discussed was the need for a journal in which to publish the original data on which climatological conclusions and prehistoric dates are based. It was, therefore, decided to publish a quarterly journal to be called the Tree Ring Bulletin, at a subscription price of 1.50 dollars a year. Dr. A. E. Douglass will be editor-in-chief; Dr. Waldo S. Glock, assistant editor ; Dr. Harold S: Colton, managing editor; and Mr. John C. MeGregor, assistant managing editor. While the publication will be of immediate interest to archæologists, it will also deal with problems of climatology and other subjects to which tree ring studies are related. Further information can be obtained from Dr. Harold S. Colton, Museum of Northern Arizona, Flagstaff, Arizona.

\section{Association of Special Libraries and Information Bureaux}

THE eleventh annual Conference of the Association of Special Libraries and Information Bureaux will be held at Somerville College, Oxford, on September 21-24, under the presidency of Sir Richard Gregory. On September 21, Sir Richard will deliver his presidential address entitled "Science in the Public Press", when the chair will be taken by the pastpresident, Sir Charles Sherrington. The morning of September 22 will be devoted to a consideration of "Book Selection for Special and General Libraries", when contributions will be made by Mr. A. F. Ridley, "Book Selection for Special Libraries"; Mr. J. E. Walker, "Methods of Selecting Technical and Refer- ence Books for General Libraries"; and Mr. S. G. Wright, "Book Recommendation Methods for University Libraries". Mr. H. V. Horton will also read a paper on "The Use of the Universal Decimal Classification in Photographic Abstracts". The afternoon will be devoted to a consideration of "Some New Libraries", when Mr. Charles Nowell will describe the "Manchester Central Library", and Mr. H. F. Alexander, the "Radeliffe Science Library, Oxford". In the evening, Mr. L. Urwick will read a paper entitled "The Idea of Planning". The morning of September 23 will be devoted to "Planning in its Relation to Information", when the following papers will be read: Mr. K. M. Lindsay, M.P., "Public Efforts at Planning in Great Britain"; and Mr. O. W. Roskill, "The Planning of Industry". In the evening, Mr. L. A. de L. Meredith will discuss "Publicity for Great Britain-Problem of the Supply of Information". In addition to members of the Association, the Conference is open to others who are interested. Further information can be obtained from the Secretary, 16, Russell Square, London, W.C.1.

\section{Announcements}

Prof. C. E. Weatherburn, professor of mathematics in the University of Western Australia, has been awarded the Hector Medal and Prize by the Royal Society of New Zealand, for his contributions to the subject of differential geometry.

Messrs. ILford LTD. have recently published a booklet entitled "Photography as an Aid to Scientific Work". It is intended as a guide to the best type of photographic material for any given problem, and as such is to be recommended as a very useful book of reference. It is a common difficulty that workers in laboratories cannot obtain a concise and informative summary of the materials and apparatus now available. In this little book, Messrs. Ilford have succeeded in furnishing such a summary relating to the photographic materials which they manufacture.

Applications are invited for the following appoint. ments, on or before the dates mentioned :-A lecturer in electrical engineering at Swindon Technical College -The Education Officer, Clarence Street, Swindon (Aug. 18). A director of the University Farm, Cambridge-The Secretary, School of Agriculture, Cambridge (Aug. 29). An engineer and ship surveyor for the Mercantile Marine Branch of the Board of TradeThe Senior Staff Officer, Establishment Department (Mercantile Marine Branch), Board of Trade, Great George Street, London, S.W.I (Sept. 12). A borough engineer and surveyor for Croydon-The Town Clerk, Town Hall, Croydon (Sept. 13). A botanist at the Royal Botanic Gardens, Kew - The Secretary, Ministry of Agriculture and Fisheries, 10, Whitehall Place, London, S.W.1 (Sept. 30). A chief chemist in the Public Health Laboratories, Cairo-The Royal Egyptian Legation, Bute House, 75, South Audley Street, London. An assistant information officer to the International Tin Research and Development Council-The Secretary, Manfield House, 378, Strand, London, W.C.2. 